\title{
Phytochemical screening, toxicity and antimicrobial activity of different Mimosa tenuiflora extracts on Aeromonas strains
}

\author{
Triagem fitoquimica, toxicidade e atividade \\ antimicrobiana de diferentes extratos de Mimosa \\ tenuiflora sobre cepas de Aeromonas
}

\author{
Aura Lacerda Crepaldi'; Aline Simões da Rocha Bispo2; Dennifier Costa \\ Brandão Cruz; Washington Luiz Gomes Tavechio3; Floricéa Magalhães Araújo4; \\ Thúlio Victor Silva Rocha ${ }^{5}$; Jackeline Pereira Andrade ${ }^{6}$; \\ Norma Suely Evangelista-Barreto ${ }^{7 *}$
}

Highlights

Aeromonas genus cause disease and mortality in fish.

Methanol proved to be the best solvent for extracting secondary metabolites.

Acute toxicity $\left(\mathrm{LC}_{50}\right.$ ) of the methanol extract of $M$. tenuiflora was considered low.

M. tenuiflora extracts are promising for the treatment of diseases in fish farms.

\begin{abstract}
The indiscriminate use of synthetic veterinary drugs in fish farms for disease control has caused recurring environmental pollution and reduced productivity; however, the search for ecologically viable alternatives is increasing. Thus, this study aimed to evaluate the phytochemical characterization of the hexanic, methanolic, and aqueous extracts of black jurema (M. tenuiflora), and their antimicrobial activity against strains of Aeromonas, and acute toxicity $\left(\mathrm{LC}_{50}\right)$ to fingerlings of $O$. niloticus. The isolates were identified,

1 Students of the Master's Course of Agricultural Microbiology, Center of Agricultural, Environmental and Biological Sciences, CCAAB, Universidade Federal do Recôncavo da Bahia, UFRB, Cruz das Almas, BA, Brazil. E-mail: a_ crepaldi@hotmail.com; dennifierbrandao@gmail.com

2 Researcher of the Master's Course of Agricultural Microbiology, CCAAB, UFRB, Cruz das Almas, BA, Brazil. E-mail: alinesimoesbispo@gmail.com

3 Researcher of the Centre for Aquaculture Health of Reconcavo, CCAAB, UFRB, Cruz das Almas, BA, Brazil. E-mail: tavechio@ufrb.edu.br

4 Prof. Dr., Metabolomics Research Group, Department of Organic Chemistry, Institute of Chemistry, Universidade Federal da Bahia, UFBA, Salvador, Brazil. E-mail: floricea@ufba.br

5 Graduate student, Forest Engineering, CCAAB, UFRB, Cruz das Almas, BA, Brazil. E-mail: silvathulio@gmail.com

6 Student of the Doctoral Course of Biotechnology, Universidade Estadual de Feira de Santana, UEFS, Feira de Santana, BA, Brazil. E-mail: jakelinepandrade@gmail.com

7 Profa Dra, CCAAB, UFRB, Cruz das Almas, BA, Brazil. E-mail: nsevangelista@ufrb.edu.br

* Author for correspondence
\end{abstract}

Received: July 19, 2021 - Approved: Dec. 02, 2021 
and phenotypic virulence and antimicrobial susceptibility tests were performed. A. caviae, and A. veronii bv. veronii showed 75.0 - 87.5\% positivity for the virulence factors tested, and resistance to the antimicrobials ampicillin, amoxicillin, erythromycin, and tetracycline of $67.0 \%$ and $50.0 \%$, respectively. Phytochemical screening of black jurema extracts detected phenols, flavonoids, tannins, saponins, alkaloids, and steroids/ triterpenoids, with methanol proving to be more efficient in the extraction of metabolites. The methanolic and aqueous extracts showed moderate antimicrobial activity, with minimum inhibitory concentration and minimum bactericidal concentration of $250 \mathrm{\mu g} \mathrm{mL}^{-1}$, and the methanolic extract revealed an $\mathrm{LC}_{50}$ of 40 $\mu \mathrm{g} \mathrm{mL}^{-1}$ for $O$. niloticus. This study demonstrated the efficiency of the in vitro antimicrobial activity of $M$. tenuiflora extracts, and their use in vivo in the treatment or prophylaxis in fish farming can be investigated to replace the use of synthetic antimicrobials.

Key words: Virulence factors. Oreochromis niloticus. Pisciculture. Antimicrobial resistance.

\section{Resumo}

O uso indiscriminado de drogas veterinárias químicas em pisciculturas para controle de doenças tem sido um problema recorrente, de poluição ambiental e redução de produtividade. Em contrapartida, a busca por alternativas ecologicamente viáveis também tem crescido. Este estudo teve por objetivo avaliar a caracterização fitoquímica dos extratos hexânico, metanólico e aquoso de jurema preta (Mimosa tenuiflora), atividade antimicrobiana em cepas de Aeromonas e toxicidade aguda do extrato $\left(\mathrm{CL}_{50}\right)$ em alevinos de Oreochromis niloticus. Também foi realizado a identificação dos isolados de Aeromonas, perfil fenotípico de virulência e suscetibilidade antimicrobiana. As cepas de $A$. caviae e $A$. veronii bv. veronii apresentaram positividade entre 75,0 - 87,5\% para os fatores de virulência testados, e resistência aos antimicrobianos, ampicilina, amoxicilina, eritromicina e tetraciclina de $67,0 \%$ e 50,0\%, respectivamente. A triagem fitoquímica dos extratos de jurema-preta detectou fenóis, flavonoides, taninos, saponinas, alcaloides e esteroides/ triterpenoides, com o metanol se mostrando o solvente mais eficiente na extração dos metabólitos secundários. Os extratos metanólico e aquoso apresentaram moderada atividade antimicrobiana, com Concentração Inibitória Mínima (CIM) e Concentração Bactericida Mínima (CBM) de $250 \mu \mathrm{g} \mathrm{mL}^{-1}$, enquanto o extrato metanólico apresentou $\mathrm{CL}_{50}$ para $O$. niloticus de $40 \mu \mathrm{g} \mathrm{mL}^{-1}$. Este estudo mostra a eficiência da atividade antimicrobiana in vitro de extratos de $M$. tenuiflora, podendo ser investigada sua utilização in vivo no tratamento ou profilaxia na piscicultura em substituição ao uso de antimicrobianos sintéticos.

Palavras-chave: Fatores de virulência. Oreochromis niloticus. Piscicultura. Resistência antimicrobiana.

\section{Introduction}

Aquatic animals and plants grow faster than any other animal production sector worldwide; therefore, aquaculture is an important production system (Romero, Feijoo, \& Navarrete, 2012). In Brazil, 722,560 thousand tons of fish were produced in 2018 , which is an increase of $4.5 \%$ compared to 2017, following the average global annual growth rates (Tacon, 2020). Although fish farming has several advantages, the development of aquaculture activity results in farming systems with high stocking densities and increased animal stress, which lead to changes in water quality (Monteiro 
et al., 2015). These conditions contribute to the emergence of microbial and parasitic diseases, requiring control measures such as the use of synthetic or natural antimicrobials (Doan, Soltani, Ingelbrecht, \& Soltani, 2020).

Antimicrobials are commonly used in the aquaculture production cycle, both for bacterial infection treatment and prophylactic measures. The excessive use of these drugs causes accumulation of their residues in the environment, which can travel through the food chain and contribute to the emergence of opportunistic and infection-resistant microorganisms that can be toxic to aquatic biota or cause allergic reactions in sensitive individuals (Monteiro et al., 2015).

In Brazil, only the antimicrobials florfenicol and oxytetracycline are licensed for aquaculture use (Sindicato Nacional da Indústria de Produtos para Saúde Animal [SINDAN], 2014). However, bacteria have become increasingly resistant to antibiotics, resulting in more expensive and longer treatments, creating a strong appeal to reduce their use (Huang \& Nitin, 2019).

Given this scenario, researchers have been looking for alternative measures to control pathogens, such as biologically active compounds present in medicinal plants with a broad spectrum of antibacterial actions (Bezerra et al., 2011; Kuebutornye \& Abarike, 2020). Black jurema (Mimosa tenuiflora) is a native plant of the Caatinga, that is widely distributed in Northeastern Brazil and known for its anti-inflammatory, curative, and antibiotic properties (Bezerra et al., 2011; Borges et al., 2017). High levels of tannins and flavonoids are associated with its antimicrobial potential (S. A. N. M. Silva et al., 2020).
The aim of the present study was to evaluate the antimicrobial activity and toxicity of different extracts of $M$. tenuiflora on Aeromonas strains isolated from ornamental fish with clinical signs of bacterial infection, to produce a possible alternative to the use of synthetic antimicrobials in the treatment of infections in fish farms.

\section{Material and Methods}

The research was conducted with authorization from the Ethics Committee in the Use of Animals (CEUA) of the Federal University of Recôncavo da Bahia (UFRB) under registration no. 23007.027506/2017-58.

\section{Obtaining fish and isolating microorganisms}

Dead fish with clinical signs of bacterial infection (eye lesions on the surface of the body and fins, and erratic swimming) were acquired from an ornamental fish farm in the municipality of Dom Macedo Costa, Bahia, Brazil.

Swabs were taken from the lesions and inoculated on glutamate agar Pseudomonas/ Aeromonas (GSP) media $\left(30{ }^{\circ} \mathrm{C} / 24 \mathrm{~h}\right)$, MacConkey agar $\left(30{ }^{\circ} \mathrm{C} / 24\right.$ h) and agar enriched with $5 \%$ of sheep blood $\left(35^{\circ} \mathrm{C} / 24\right.$ h) (Alexandrino et al., 1999; Salvador et al., 2005; N. Silva et al., 2010b). After incubation, typical Aeromonas colonies were seeded on tryptic soy agar (ATS) for phenotypic (oxidase and catalase) and morphotintorial (gram stain) characterizations. 
Molecular identification of isolates and phylogenetic reconstruction

DNA was extracted according to the methodology described by Lee, Kim, Liul and Lee (2003) with modifications. The isolates were grown in nutrient broth for $24 \mathrm{~h}$, polyvinylpyrrolidone and 2-mercaptoethanol were removed from the lysis solution, and potassium acetate was added. To precipitate the DNA, isopropanol and ammonium acetate were included. Primers 8 F (5'-AGAGTTTGATCCTGGCTCAG-3') and 1492R (5'-ACGGCTACCTTGTTACGACTT-3') (Miyashita et al., 2009) were used to amplify and sequence the 16S rRNA gene (Leite et al., 2013). The PCR products were sequenced at the company ACTGene Analisis Moleculares Ltda, using an $A B 3500$ sequencer (Applied Biosystems, California, USA). The sequences were edited using Sequencher v.5 program. 4.6, and compared using the BLASTn program with other sequences deposited in public databases.

The 16S rRNA type species sequences were retrieved from the List of Prokaryotic names with Standing in Nomenclature (LPSN) in August 2018 (Euzéby, 1997). MEGA v. 6.0 was used to align and perform the phylogenetic analysis of the sequences with the maximum likelihood method and with 1000-repeat bootstrap analysis. The Hasegawa-Kishino-Yano model with gamma distribution and invariant sites was selected as the best nucleotide replacement model.

\section{Antimicrobial susceptibility}

The susceptibility profile of the isolates was determined using the disk diffusion technique with a bacterial density of $10^{8}$ CFU mL ${ }^{-1}$ (Clinical and Laboratory Standards Institute [CLSI], 2018). The antimicrobials amoxicillin $(10 \mu \mathrm{g})$, tetracycline $(30 \mu \mathrm{g})$, ampicillin $(10 \mu \mathrm{g})$, chloramphenicol $(30 \mu \mathrm{g})$, streptomycin $(10 \mu \mathrm{g})$ and erythromycin $(15$ $\mu \mathrm{g})$ were tested. The inhibition zones were classified as sensitive $(\geq 18 \mathrm{~mm})$, intermediate (13-17 mm), and resistant ( $\leq 13 \mathrm{~mm}$ ) (Odeyemi \& Ahmad, 2015) for the interpretation of the results. The multiple antimicrobial resistance index (MAR) was also used (Osundiya, Oladele, \& Oduyebo, 2013).

\section{Phenotypic virulence tests}

To detect exoenzymes, the strains were grown on TSA agar containing $1 \% \mathrm{NaCl}$ and supplemented with $0.5 \%$ gelatin (gelatinase), $5 \%$ skimmed milk powder (casein), 1\% egg yolk emulsion (phospholipase), 1\% Tween 80 (lipase), 20\% sheep erythrocyte solution (hemolysin), 0.1\% starch (amylase), urea broth (urease), and DNase agar supplemented with $0.01 \%$ toluidine chloride (DNase). Halo formation indicated test positivity (Wagatsuma, 1968; Hongping, Jilun, Ting, Yixi, \& Xiaoming, 2011; I. P. Silva et al., 2018).

\section{Preparation of plant extracts}

The plant material was collected in the municipality of Cruz das Almas, Bahia $\left(12^{\circ} 39^{\prime} 13.0^{\prime \prime} \mathrm{S}, 39^{\circ} 05^{\prime} 06.1^{\prime \prime} \mathrm{W}\right)$ and its exsiccate is deposited in the Recôncavo da Bahia Herbarium under the number (HURB 18333). The stem bark of $M$. tenuiflora was dried at room temperature $\left(25 \pm 2^{\circ} \mathrm{C}\right)$, crushed in a knife mill, and subjected to maceration in hexane and methanol three times for each solvent. 
The material was filtered and concentrated using a rotary evaporator at $30{ }^{\circ} \mathrm{C}$. To obtain the aqueous extract, the dried and ground material was macerated in sterile distilled water at room temperature, refrigerated for 24 $\mathrm{h}$, filtered, and lyophilized at $-20^{\circ} \mathrm{C}$.

Antimicrobial activity of Mimosa tenuiflora extract

The microdilution plate test was performed using two standard strains (Pseudomonas aeruginosa ATCC 27853 and Staphylococcus aureus ATCC 25923) and Aeromonas, following the methodology of CLSI (2012). For the minimum inhibitory concentration $(\mathrm{MIC})$, the three extracts were diluted in 10\% DMSO concentrations from 7.81 to $1000 \mu \mathrm{g} \mathrm{mL} \mathrm{L}^{-1}$. The minimum bactericidal concentration (MBC) was defined as the lowest concentration capable of causing cell death (CLSI, 2012).

\section{Phytochemical screening}

The extracts were subjected to qualitative phytochemical analysis to detect the main classes of secondary metabolites, following the methodologies of N. L. A. Silva, Miranda and Conceição (2010a) and Joshi, Bhobe and Sattarkar (2013). Preliminary techniques were performed to detect flavonoids (Shinoda test), tannins (iron precipitation test), saponins and alkaloids (Drangendorff), and steroids and triterpenoids (Liebermann-Burchard and Salkowski).
Determination of the content of total phenols, tannins and flavonoids

Total phenol content was determined using the Folin-Ciocalteu method from a solution containing $100 \mu \mathrm{L}$ of each extract diluted in $25 \mathrm{~mL}$ of methanol. A $100 \mu \mathrm{L}$ aliquot was stirred into $500 \mu \mathrm{L}$ of Folin-Ciocalteu reagent and $6 \mathrm{~mL}$ of distilled water for $1 \mathrm{~min}$. Then, $2 \mathrm{~mL}$ of $20 \% \mathrm{Na}_{2} \mathrm{CO}_{3}$ was added and the solution was stirred for $1 \mathrm{~min}$, rested for $2 \mathrm{~h}$ and the results read at $750 \mathrm{~nm}$. Gallic acid (0.9 to $6.3 \mathrm{mg} \mathrm{L}^{-1}$ ) was used for the calibration curve: $y=0.0983 x+0.0355\left(R^{2}=0.992\right)$. The results were expressed in $\mathrm{mg}$ of gallic acid equivalents (GAE) per gram of extract (Meda, Lamien, Romito, Millogo, \& Nacoulma, 2005).

The tannin content was determined using the vanillin/ $\mathrm{HCl}$ method. One milliliter of each extract was diluted in methanol, added to $5 \mathrm{~mL}$ of a $1 \%$ vanillin and $8 \% \mathrm{HCl}$ solution (1:1), rested for $20 \mathrm{~min}$ at $30{ }^{\circ} \mathrm{C}$, and read at $500 \mathrm{~nm}$. For the calibration curve, the catechin standard (200 - $\left.1000 \mathrm{mg} \mathrm{mL}^{-1}\right)$ and the calibration equation: $y=0.0004 x+0.0128$ $\left(R^{2}=0.998\right)$ were used. The results were expressed in grams of catechin equivalent $100 \mathrm{~g}^{-1}$ extract (Missio et al., 2017).

The total flavonoid content was determined according to Meda et al. (2005). Fifty microliters of each extract was homogenized in a methanolic solution of $\mathrm{AlCl}_{3}$ (2\%), kept in the dark for 30 min, and read at $415 \mathrm{~nm}$. For the calibration curve, rutin (10 $100 \mu \mathrm{g} \mathrm{mL}^{-1}$ ) was used based on $\mathrm{y}=0.0146 \mathrm{x}+$ $0.2147\left(R^{2}=0.999\right)$. The results are expressed as percentages. 


\section{Acute toxicity test ( $\left(\mathrm{C}_{50}\right)$}

The MIC of the $M$. tenuiflora extract responsible for causing $50 \%$ mortality of $O$. niloticus fingerlings was determined by first exposing the fish to different concentrations of the extract diluted in 10\% DMSO $\left(\mu \mathrm{g} \mathrm{mL}^{-1}\right)$ $(\mathrm{T} 1=250, \mathrm{~T} 2=75, \mathrm{~T} 3=50, \mathrm{~T} 4=25$, and $\mathrm{T} 5$ = 10), a positive control with 10\% DMSO (T6), and a negative control using only water (T7). All treatments were performed with three replicates and five fish per repetition in a completely randomized design (CRD). The experiment was conducted in aquariums containing $5 \mathrm{~L}$ of water, light, and constant aeration in an air-conditioned environment, with individuals weighing $1 \mathrm{~g}$ and a maximum density of $1 \mathrm{~g} \mathrm{~L}^{-1}$ (Instituto Brasileiro do Meio Ambiente e dos Recursos Naturais Renováveis [IBAMA], 1987). Mortality was assessed daily, and the $\mathrm{LC}_{50}$ at $48 \mathrm{~h}$ was determined using the trimmed Spearman-Karber method (Hamilton, Russo, \& Thurston, 1977).

\section{Results and Discussion}

The main bacteria responsible for losses in fish farms belong to the Aeromonas genus, which has complex pathogenicity related to multiple factors, such as the production of enzymes and extracellular toxins (Sreedharan, Philip, \& Singh, 2013), indicating the virulent potential of these microorganisms. In this study, genetic analysis showed that strains A4 and E5 were closely related to $A$. caviae (ATCC15468) and $A$. veronii bv. veronii (ATCC 35624), respectively, with $100 \%$ homology (Figure 1). The presence of $A$. veronii bv. veronii was also identified by 16S rRNA in diseased fish that had internal hemorrhage and necrosis of the tail and fins, which were acquired from an ornamental fish farm in Kerala, India (Sreedharan et al., 2013).

Aeromonas strains showed resistance to ampicillin and intermediate resistance to tetracycline, which can be attributed to the wide use of these antimicrobials due to their broad spectrum of action, low toxicity, and low cost (Scarano et al., 2018). Aeromonas veronii showed greater susceptibility (50\%) to antimicrobials than $A$. caviae (33.3\%). When grouping the resistance and intermediate resistance categories, $A$. caviae presented $67 \%$ resistance to antimicrobials, and $A$. veronii showed $50 \%$ resistance (Table 1 ). Similar results were reported by Suhet, Schocken-Iturrino and Amaral (2011), who observed $100 \%$ resistance to amoxicillin and $50 \%$ to erythromycin for $A$. caviae, and $100 \%$ to amoxicillin, and $50 \%$ to tetracycline for $A$. veronii. According to Jagoda, Honein, Arulkanthan, Ushio and Asakawa (2017), A. veronii has increasingly attracted the attention of researchers due to its virulence potential in a wide range of hosts, both as a primary and an opportunistic pathogen, as well as its capacity to develop multidrug resistance phenotypes. 


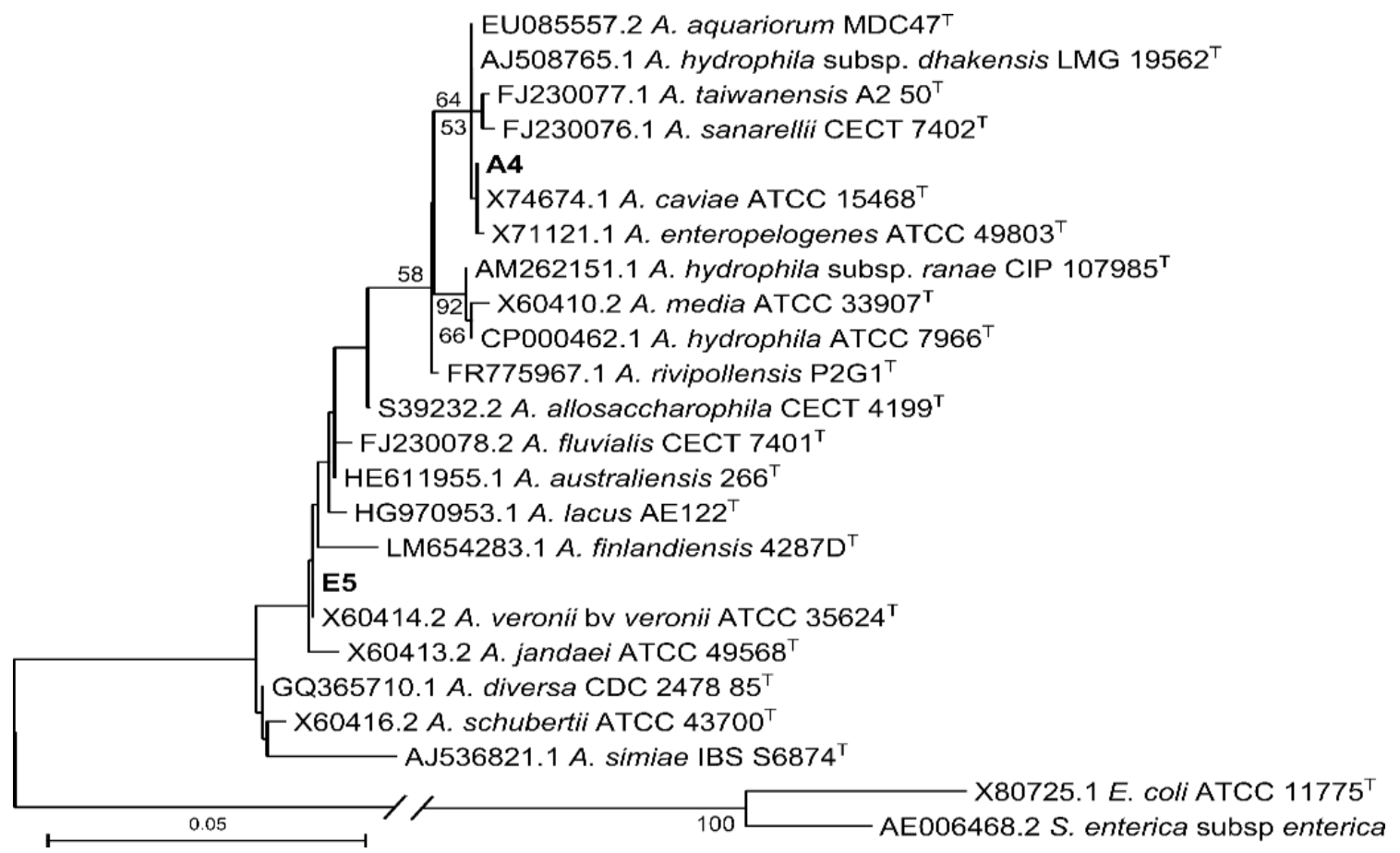

Figure 1. Phylogenetic tree showing the relationship of bacterial isolates obtained (in bold) with the species of the genus Aeromonas. Only bootstrap values above 50 are shown. E. coli (X80725) and Salmonella enterica subsp. enterica (AE006468) were used as outgroups. The scale indicates the number of replacements per site.

Table 1

Antimicrobial resistance profile of Aeromonas caviae and $A$. veronii bv. veronii against synthetic antimicrobials

\begin{tabular}{|ccc|}
\hline & & Bacteria \\
\cline { 2 - 3 } Antimicrobials & A. caviae & A. veronii bv. veronii \\
\hline Amoxicillin & $15.83(\mathrm{I})$ & $11.44(\mathrm{R})$ \\
\hline Tetracycline & $15.12(\mathrm{I})$ & $15.76(\mathrm{I})$ \\
\hline Ampicillin & $5.91(\mathrm{R})$ & $6.93(\mathrm{R})$ \\
\hline Chloramfhenicol & $29.4(\mathrm{~S})$ & $45.68(\mathrm{~S})$ \\
\hline Streptomycin & $23.88(\mathrm{~S})$ & $22.09(\mathrm{~S})$ \\
\hline Erytromycin & $12.03(\mathrm{R})$ & $18.82(\mathrm{~S})$ \\
\hline
\end{tabular}

$\mathrm{S}=$ sensitive. $\mathrm{I}$ = intermediate resistance. $\mathrm{R}=$ resistant.

The antimicrobial multidrug resistance (AMR) index for $A$. caviae was 0.67 , indicating resistance to four antimicrobials and 0.50 for $A$. veronii, denoting resistance to three antimicrobials. Multiple resistance to at least four antimicrobials of more than three 
structural classes was also reported by Hossain et al. (2019) with Aeromonas strains isolated from healthy ornamental fish in Korea, demonstrating the excessive use of antimicrobials in that industry. According to Shuang et al. (2020), the increase in antimicrobial resistance in cultured Aeromonas strains has increased due to the abusive use of these drugs in rearing systems, causing the bacteria to carry the resistance genes through horizontal transfer.

For phenotypic virulence tests, $A$. caviae was negative for urease, and $A$. veronii for DNase and urease of the eight factors tested. Despite the multiple virulence factors found in the strains, J. L. S. Silva et al. (2016) reported that determining the relevance of the various factors is infeasible, as they all are relevant for establishing infection. The production of microbial exoenzymes promotes tissue destruction, immune system cell lysis, and host cell invasion (Otto, 2014). This justifies the hypothesis that the bacteria $A$. caviae and $A$. veronii were responsible for the infection that caused fish mortality in the studied fish farm.
Both species were characterized with positive $\beta$-hemolysis. Sreedharan et al. (2013) stated that $\beta$-hemolysis is one of the most important virulence factors in the pathogenicity process in fish, since hemolysins are extracellular cytolytic proteins capable of destroying membrane permeability barriers by inserting into the lipid bilayer and destroying the red blood cells.

In fish farms, another constraint encountered by producers is an increase in bacterial resistance in environmental isolates. Therefore, the antibacterial activity of $M$. tenuiflora extracts was analyzed and the same MIC and MBC values were obtained for the bacteria, with the methanolic and aqueous extracts showing greater efficiency for Aeromonas than for the reference strains (Table 2). According to Simonetti et al. (2016), the methanolic and aqueous extracts showed moderate antimicrobial activity (MIC between 100 and $500 \mu \mathrm{g} \mathrm{mL}^{-1}$ ) for Aeromonas and S. aureus and weak antimicrobial activity against $P$. aeruginosa (MIC between 500 and $1000 \mu \mathrm{g}$ $\left.\mathrm{mL}^{-1}\right)$. The hexane extract was inactive against all tested microorganisms (MIC $>1000 \mu \mathrm{g} \mathrm{mL}^{-1}$ ).

\section{Table 2}

Minimum Inhibitory Concentration (MIC) and Minimum Bactericidal Concentration (MBC) of M. tenuiflora extracts against Aeromonas and reference strains

\begin{tabular}{|ccccccc}
\hline & \multicolumn{7}{c}{ Extracts $\left(\mu \mathbf{g ~ m L}^{-1}\right)$} \\
\cline { 2 - 7 } Pathogens & \multicolumn{2}{c}{ HEMT } & \multicolumn{2}{c}{ MEMT } & \multicolumn{2}{c|}{ AEMT } \\
& CIM & CBM & CIM & CBM & CIM & CBM \\
A. caviae & $>1000$ & $>1000$ & 250 & 250 & 250 & 250 \\
A. veronii bv. veronii & $>1000$ & $>1000$ & 250 & 250 & 250 & 250 \\
P. aeruginosa ATCC 27853 & $>1000$ & $>1000$ & 1000 & 1000 & 1000 & 1000 \\
S. aureus ATCC 25923 & $>1000$ & $>1000$ & 500 & 500 & 500 & $>1000$
\end{tabular}

HEMT: hexane extract of $M$. tenuiflora; MEMT: methanol extract of $M$. tenuiflora; AEMT: aqueous extract of $M$. tenuiflora. MIC: Minimum Inhibitory Concentration. MBC: Minimum Bactericidal Concentration. 
The phytochemical analysis of the extracts (Table 3 ) showed that the hexane extract did not contain flavonoid compounds or tannins, as observed in the methanolic and aqueous extracts, while steroids/triterpenoids were present in the hexane extract and absence in the other extracts. Phytochemical compounds play a fundamental role in investigating the active principles of medicinal plants, as their presence contributes to the development of new drugs (Cordell, 2014).

The antimicrobial activity of $M$. tenuiflora extract has been associated with the presence of tannins (S. A. N. M. Silva et al., 2020). As noted, these compounds were not found in the hexane extract, which had low antimicrobial activity (MIC $>1000 \mu \mathrm{g} \mathrm{mL}^{-1}$ )
(Table 2). Tannins are mainly responsible for the antimicrobial activity of $M$. tenuiflora, and among the mechanisms of action are enzymes inhibition, cell membrane rupture, and metal ion complexation, which reduce important elements of microbial metabolism and affect its physiology (Ferreira \& Evangelista, 2021). The presence of tannins in extracts can be attributed to their polarity and ability to bind to polar solvents such as methanol and water. Hexane is a low-polarity solvent and shows less efficiency in extracting compounds (Meira et al., 2020). Similar results were reported by S. A. N. M. Silva et al. (2020) who observed that ethanol solvent polarity promoted better retrieval of metabolic compounds such as tannins and flavonoids in $M$. tenuiflora extracts.

\section{Table 3}

Phytochemical screening of the three extracts obtained from the stem bark of M. tenuiflora

$\begin{array}{cccc}\text { Phytochemical tests } & \text { HEMT } & \text { MEMT } & \text { AEMT } \\ \text { Flavonoids } & - & + & + \\ \text { Tannins } & - & + & + \\ \text { Saponins } & + & + & + \\ \text { Alkaloids } & + & - & -\end{array}$

HEMT: hexane extract of $M$. tenuiflora; MEMT: methanol extract of $M$. tenuiflora; AEMT: aqueous extract of $M$. tenuiflora; (+): presence; (-): absence.

As flavonoids were not found in the hexane extract screening, the quantification of total phenols and tannins was performed only in the methanolic and aqueous extracts. The methanolic extract had a higher content of secondary metabolites compared to the aqueous extract, while both contained more than $50 \%$ of tannins (Table 4). The methanol extract has a higher content of total phenols and tannins; therefore, it was chosen to test the acute toxicity in Nile tilapia fingerlings. 


\section{Table 4}

Quantification of total phenols, tannins and flavonoids in aqueous and methanolic extracts of $M$. tenuiflora

\begin{tabular}{cccc} 
Extracts & $\begin{array}{c}\text { Total phenols } \\
\text { (g de GAE/100g de extract) }\end{array}$ & $\begin{array}{c}\text { Tannins } \\
\text { (g de CE/100g de extract) }\end{array}$ & $\begin{array}{c}\text { Flavonoids } \\
\text { (\% de ER) }\end{array}$ \\
\hline AEMT & $1.42 \pm 0.01$ & $59.10 \pm 7.58$ & 0.47 \\
MEMT & $2.20 \pm 0.14$ & $69.25 \pm 11.68$ & 0.72 \\
\hline
\end{tabular}

MEMT: methanol extract of $M$. tenuiflora; AEMT: aqueous extract of $M$. tenuiflora; GAE: gallic acid equivalent; CE: catechin equivalent; ER: equivalent of routine.

Regarding acute toxicity $\left(\mathrm{LC}_{50}\right)$, concentrations of $250 \mu \mathrm{m} \mathrm{mL}^{-1}$ (T1) and $75 \mu \mathrm{g} \mathrm{mL} \mathrm{L}^{-1}$ (T2) caused $100 \%$ mortality of O. niloticus fingerlings, while $50 \mu \mathrm{g} \mathrm{mL}-1$ (T3) caused $60 \%$ mortality and the control treatments (T6 and T7) showed no mortality. The $\mathrm{LC}_{50}$ of the methanol extract of $M$. tenuiflora for fingerlings was considered low $\left(40 \mu \mathrm{g} \mathrm{mL}^{-1}\right)$. According to the classification of acute toxicity for aquatic organisms (Zucker, 1985), the methanol extract of $M$. tenuiflora is considered slightly toxic (values $>10$ to $<100$ ), which helps to determine safe doses for use in fish farming. Thus, the antimicrobial use of plant extracts is a promising method of controlling diseases in fish, as it is easily biodegradable, low-cost, and accumulates less waste in fish (Awad \& Awaad, 2017; Doan et al., 2020). Among the secondary metabolites identified in black jurema are the flavonoids apigenin and flavonol (Borges et al., 2017), sakuranetine (5,4'-dihydroxy-7methoxyflavanone), and sorbifolium $\left(5,6,4^{\prime}-\right.$ trihydroxy-7-methoxyflavone) (Hernandez et al., 2021), 5,7,4'-trihydroxy-3-methoxyflavone, 5,4'-dihydroxy-7,8-dimethoxyflavone, $5,7,4$ '-trihydroxy-6-methoxyflavonol, and 5-hydroxy7,8,4'-trimethoxyflavonol (Cruz et al., 2016), saponins, alkaloids, polysaccharides, and anthraquinones (Bezerra et al., 2011). However, it is believed that the use of bioactive compounds promotes the slower development of microbial resistance, and the application of inadequate doses of herbal medicines can cause toxicity (Reverter, Bontemps, Lecchini, Banaigs, \& Sasal, 2014).

Similar fish reactions to initial exposure of higher extract concentrations (T1, T2, and T3) were observed, such as increased opercular beat, agitation, and erratic swimming. These reactions may be associated with a rapid decrease in dissolved oxygen in water, as evidenced by increased opercular movement, as well as the toxic effect caused by the compounds present in the extract (Kuebutornye \& Abarike, 2020). Considering that the extract of $M$. tenuiflora showed acute toxicity for $O$. niloticus at a concentration six times lower than the MIC of the extract for $A$. caviae and $A$. veronii, it is suggested that future studies should test the exposure period of fish to the extract lesser than $48 \mathrm{~h}$, as well as its antibacterial activity in vivo. Another alternative would be the use of the aqueous extract, which in vitro showed the same MIC for the bacteria, and 15\% less tannins when compared to the methanolic extract. 
Despite the bioactivity of some plants as an antioxidant, antimicrobial, or immunostimulant agents in the control of fish diseases or weight gain (Durmic \& Blache, 2012), further studies on the use of black jurema extract are required in terms of absorption, metabolism, and biological action in animals to assess its potential effect on aquaculture production systems.

\section{Conclusion}

Methanolic and aqueous extracts of $M$. tenuiflora showed strong antibacterial activity in vitro against pathogenic $A$. caviae and $A$. veronii bv. veronii, which is promising for its application in the prophylaxis and treatment of microbial diseases associated with fish production. Another important discovery was the low toxicity of the extracts for Nile tilapia, which could enable their use in sublethal doses. Thus, these extracts can be applied in fish farms as an efficient alternative for the treatment of quarantined fish affected by microbial diseases with the aim of replacing conventional antimicrobials.

\section{Acknowledgments}

The authors are grateful for the financial support from Coordenação de Aperfeiçoamento de Pessoal de Nível Superior - Brazil (CAPES) - Finance Code 001.

\section{References}

Alexandrino, A., Okumura, M., Baladassi, L., Tabata, Y., Pauli, A., Araújo, A., \& Rosa, M. (1999). Occurrence of Edwardsiella tarda infection in rainbow trout (Oncorhynchus mykiss) under intensive culture system. Boletim do Instituto de Pesca, 25(1), 121-123. Retrieved from: https://pesca. agricultura.sp.gov.br/boletim/index.php/ bip/article/view/656

Awad, E., \& Awaad, A. (2017). Role of medicinal plants on growth performance and immune status in fish. Fish \& Shellfish Immunology, 67(1), 40-54. doi: 10.1016/j. fsi.2017.05.034

Bezerra, D. A. C., Rodrigues, F. F. G., Costa, J. G. M., Pereira, A. V., Sousa, E. O., \& Rodrigues, O. G. (2011). Abordagem fitoquímica, composição bromatológica e atividade antibacteriana de Mimosa tenuiflora (Wild) Poiret e Piptadenia stipulacea (Benth) Ducke. Acta Scientiarum. Biological Sciences, 33(1), 99-106. doi: 10.4025/ actascibiolsci.v33i1.5366

Borges, I. V., Cavalcanti, L. S., Figueirêdo, A., Neto, Almeida, J. R. G. S., Rolim, L. A., \& Araújo, E. C. C. (2017). Identificação da fração antimicrobiana do extrato da Mimosa tenuiflora. Comunicata Scientiae, 8(1), 155-159. doi: 10.14295/cs.v8i1.1493

Clinical and Laboratory Standards Institute (2012). Methods for dilution antimicrobial susceptibility tests for bacteria that grow aerobically; approved standard (9nd ed., M7-A9). Wayne, PA: CLSI.

Clinical and Laboratory Standards Institute (2018). Performance standards for antimicrobial susceptibility testing (28nd ed., supplement M100). Wayne, PA: CLSI.

Cordell, G. A. (2014). Phytochemistry and traditional medicine - the revolution continues. Phytochemistry Letters, 10(1), 28-40. doi: 10.1016/j. phytol.2014.06.002 
Cruz, M. P., Andrade, C. M. F., Silva, K. O., Souza, E. P. de, Yatsuda, R., Marques, L. M.,... Clemente-Napimoga, J. T. (2016). Antinoceptive and anti-inflammatory activities of the ethanolic extract, fractions and flavones isolated from Mimosa tenuiflora (Willd.) Poir (Leguminosae). PLoS One, 11(3), e0150839. doi: 10.1371/ journal.pone.0150839

Doan, H. V., Soltani, E., Ingelbrecht, J., \& Soltani, M. (2020). Medicinal herbs and plants: potential treatment of monogenean infections in fish. Reviews in Fisheries Science \& Aquaculture, 28(2), 260-282. doi: $10.1080 / 23308249.2020 .1712325$

Durmic, Z., \& Blache, D. (2012). Bioactive plants and plant products: effects on animal function, health and welfare. Animal Feed ScienceandTechnology, 176(1-4), 15-162. doi: 10.1016/j.anifeedsci.2012.07.018

Euzéby, J. P. (1997). List of bacterial names with standing in nomenclature: a folder available on the internet. International Journal of Systematic and Evolutionary Microbiology, 47(2), 590-592. doi: 10.10 99/00207713-47-2-590

Ferreira, T. L., \& Evangelista, A. J. J. (2021). Mimosa tenuiflora's antimicrobial activity on bacteria and fungi from medical importance: an integrative review. Archives of Microbiology, 203(6), 33993406. doi: 10.1007/s00203-021-02330-6

Hamilton, M. A., Russo, R. C., \& Thurston, R. V. (1977). Trimmed Spearman-Karber method for estimating median lethal concentrations in toxicity bioassays. Environmental Science \& Technology, 11(7), 714-719. doi: 10.1021/es60130a 004
Hernandez, C., Cadenillas, L., El Maghubi, A., Caceres, I., Durrieu, V., Mathieu, C., \& Bailly, J.-D. (2021). Mimosa tenuiflora aqueous extract: role of condensed tannins in anti-aflatoxin b1 activity in Aspergillus flavus. Toxins, 13(6), 391. doi: 10.3390/ toxins 13060391

Hongping, W., Jilun, Z., Ting, J., Yixi, B., \& Xiaoming, Z. (2011). Insufficiency of the Kanagawa hemolytic test for detecting pathogenic Vibrio parahaemolyticus in Shanghai, China. Diagnostic Microbiology and Infectious Disease, 69(1), 7-11. doi: 10.1016/j.diagmicrobio.2010.08.016

Hossain, S., Silva, B. C. J., Wimalasena, S. H. M. P., Pathirana, H. N. K. S., Dahanayake, P. S., \& Heo, G.-J. (2019). Characterization of virulence determinants and multiple antimicrobial resistance profiles in motile Aeromonas spp. isolated from ornamental goldfish (Carassius auratus). Journal of Exotic Pet Medicine, 29(1), 51-62. doi: 10.1053/j.jepm.2018.09.013

Huang, K., \& Nitin, N. (2019). Edible bacteriophage based antimicrobial coating on fish feed for enhanced treatment of bacterial infections in aquaculture industry. Aquaculture, 502(1), 18-25. doi: 10.1016/j.aquaculture. 2018.12.026

Instituto Brasileiro do Meio Ambiente e dos Recursos Naturais Renováveis (1987). Avaliação da toxicidade aguda para peixes. (Manual de testes para avaliação de ecotoxicidade de agentes químicos, parte D. 3). Brasília: Ibama.

Jagoda, S. S. S. S., Honein, K., Arulkanthan, A., Ushio, H., \& Asakawa, S. (2017). Genome sequencing and annotation 
of Aeromonas veronii strain Ae52, a multidrug-resistant isolate from septicaemic gold fish (Carassius auratus) in Sri Lanka. Genomics Data, 11(1), 46-48. doi: 10.1016/j.gdata.2016.11.011

Joshi, A., Bhobe, M., \& Sattarkar, A. (2013). Phytochemical investigation of the roots of Grewia microcos Linn. Journal of Chemical and Pharmaceutical Research, 5(7), 80-87. Retrieved from https://www. advion.com/wp-content/uploads/Joshi_ Goa.pdf

Kuebutornye, F. K. A., \& Abarike, E. D. (2020). The contribution of medicinal plants to tilapia aquaculture: A review. Aquaculture International, 28(1), 965-983. doi: 10.10 07/s10499-020-00506-3

Lee, Y. K, Kim, H. W., Liul, C. L., \& Lee, H. K. (2003). A simple method for DNA extration from marine bacteria that produce extracellular materials. Journal of Microbiological Methods, 52(2), 245-250. doi: 10.1016/ s0167-7012(02)00180-x

Leite, H. A. C., Silva, A. B., Gomes, F.P., Gramacho, K. P., Souza, J. T., \& Loguercio, L. L. (2013). Bacillus subtilis and Enterobacter cloacae endophytes from healthy Theobroma cacao L. trees can systemically colonize seedlings and promote growth. Applied Microbiology and Biotechnology, 97(6), 2639-2651. doi: 10.1007/s00253-012-45 $74-2$

Meda, A., Lamien, C. E., Romito, M., Millogo, J., \& Nacoulma, O. G. (2005). Determination of the total phenolic, flavonoid and proline contents in Burkina Fasan honey, as well as their radical scavenging activity. Food Chemistry, 9(3), 571-577. doi: 10.1016/j. foodchem.2004.10.006
Meira, C. L. C., Novaes, C. G., Novais, F. C., Jesus, V. S., Oliveira, D. M., \& Aguiar, R. M. (2020). Application of principal component analysis for the evaluation of the chemical constituents of Mimosa tenuiflora methanolic extract by DLLME/GC-MS. Microchemical Journal, 152(1), 104284. doi: 10.1016/j.microc. 2019.104284

Missio, A.L., Tischer, B., Santos, P.S.B., Codevilla, C., Menezes, C. R., Barin, J. S.,... Tondi, G. (2017). Analytical characterization of purified mimosa (Acacia mearnsii) industrial tannin extract: Single and sequential fractionation. Separation and Purification Technology, 186(1), 218-225. doi: 10.1016/j.seppur.2017.06.010

Miyashita, A., Mochimaru, H., Kazama, H., Ohashi, A., Yamaguchi, T., Nunoura, T.,... Imachi, H. (2009). Development of $16 \mathrm{~S}$ rRNA gene-targeted primers for detection of archaeal anaerobic methanotrophs (ANMEs). Fems Microbiology Letters, 297(1), 31-37. doi: 10.1111/j.1574-6968. 2009.01648.x

Monteiro, S. H., Francisco, J. G., Campion, T. F., Pimpinato, R. F., Moura Andrade, G. C. R., Garcia, F., \& Tornisielo, V. L. (2015). Multiresidue antimicrobial determination in Nile tilapia (Oreochromis niloticus) cage farming by liquid chromatography tandem mass spectrometry. Aquaculture, 447(1), 37-43. doi: 10.1016/j.aquaculture. 2015.07.002

Odeyemi, O. A., \& Ahmad, A. (2015). Antibiotic resistance profiling and phenotyping of Aeromonas species isolated from aquatic sources. Saudi Journal of Biological Sciences, 24(1), 65-70. doi: 10.1016/j. sjbs.2015.09.016 
Osundiya, O. O., Oladele, R. O., \& Oduyebo, O. O. (2013). Multiple Antibiotic Resistance (MAR) indices of Pseudomonas and Klebsiella species isolates in Lagos University Teaching Hospital. African Journal of Clinical and Experimental Microbiology, 14(3), 164-168. doi: 10.43 14/ajcem.v14i3.8

Otto, M. (2014). Staphylococcus aureus toxins. Current Opinion in Microbiology, 17(1), 32-37. doi: 10.1016/j.mib.2013.11.004

Reverter, M., Bontemps, N., Lecchini, D., Banaigs, B., \& Sasal, P. (2014). Use of plant extracts in fish aquaculture as an alternative to chemotherapy: Current status and future perspectives. Aquaculture, 433(1), 50-61. doi: 10.1016/j.aquaculture.2014.05.048

Romero, J., Feijoo, C. G., \& Navarrete, P. (2012). Health and environment in aquaculture. In E. D. Carvalho, G. S. David, \& R. J. Silva (Eds.), Antibiotics in aquaculture - use, abuse and alternatives (pp. 159-198). London: IntechOpen. doi: 10.5772/28157 Retrieved from https://app.dimensions.ai/ details/publication/ pub.1087205154

Salvador, R., Muller, E. E., Freitas, J. C., Leonhadt, J. H., Pretto-Giordano, L. G., \& Dias, J. A. (2005). Isolation and characterization of Streptococcus spp. group B in Nile tilapias (Oreochromis niloticus) reared in hapas nets and earth nurseries in the northern region of Parana State, Brazil. Ciência Rural, 35(6), 1374-1378. doi: 10.1590/ s0103-84782005000600023

Scarano, C., Piras, F., Virdis, S., Ziino, G., Nuvoloni, R., Dalmasso, A.,... Spanu, C. (2018). Antibiotic resistance of Aeromonas ssp. strains isolated from Sparus aurata reared in Italian mariculture farms. International Journal of Food Microbiology, 284(1), 91-97. doi: 10.1016/j.ijfoodmicro.2018.07.033

Shuang, M., Yong, L. W., Chen, G. L., Jing, Y., Min, Y., Xiang, N. B.,... Juan, L. (2020). Genetic diversity, antimicrobial resistance, and virulence genes of Aeromonas isolates from clinical patients, tap water systems, and food. Biomedical and Environmental Sciences, 33(6), 385-395. doi: 10.3967/ bes 2020.053

Silva, I. P., Carneiro, C. S., Saraiva, M. A. F., Oliveira, T. A. S., Sousa, O. V., \& EvangelistaBarreto, N. S. (2018). Antimicrobial resistance and potential virulence of Vibrio parahaemolyticus isolated from water and bivalve mollusks from Bahia, Brazil. Marine Pollution Bulletin, 131(1), 757-762. doi: 10.1016/j.marpolbul.2018.05.007

Silva, J. L. S., Cavalcante, D. de H., Carvalho, F. C. T. de, Vieira, R. H. S. dos F., Sá, M. V. do C., \& Sousa, O. V. (2016). Aquatic microbiota diversity in the culture of Nile tilapia (Oreochromis niloticus) using bioflocs or periphyton: virulence factors and biofilm formation. Acta Scientiarum. Animal Sciences, 38(3), 233-241. doi: 10. 4025/actascianimsci.v38i3.31910

Silva, N., Junqueira, V. C. A., Silveira, N. F. A., Taniwaki, M. H., Santos, R. F. S., \& Gomes, R. A. R. (2010b). Manual de métodos de análise microbiológica de alimentos e água. São Paulo, SP: Varela.

Silva, N. L. A., Miranda, G. M., \& Conceição, G. M. (2010a). Triagem fitoquímica de plantas de cerrado, da área de proteção ambiental municipal do Inhamum, Caxias, Maranhão. Scientia Plena, 6(2), 025402. Retrieved from https://scientiaplena. emnuvens.com.br/sp/article/view/22 
Silva, S. A. N. M., Barros, A. B., Souza, J. M. T., Moura, A. F., Araújo, A., R., Mendes, M. G. A.,... Marinho, J. D. B., Fo. (2020). Phytochemical and biological prospection of Mimosa genus plants extracts from Brazilian northeast. Phytochemistry Letters, 39(1), 173-181. doi: 10.1016/j. phytol.2020.08.010

Simonetti, E., Ethur, M. E., Castro, L. C., Kauffmann, C., Giacomin, A. C., Ledur, A.,... Freitas, E. M. (2016). Avaliação da atividade antimicrobiana de extratos de Eugenia anomala e Psidium salutare (Myrtaceae) frente à Escherichia coli e Listeria monocytogenes. Revista Brasileira de Plantas Medicinais, 18(1), 9-18. doi: 10.1590/1983-084X/15_005

Sindicato Nacional da Indústria de Produtos para a Saúde Animal (2014). Compêndio de produtos veterinários. São Paulo, SP: SINDAN. Recuperado de https://sistemas. sindan.org.br/cpvs/

Sreedharan, K., Philip, R., \& Singh, I. S. B. (2013). Characterization and virulence potential of phenotypically diverse Aeromonas veronii isolates recovered from moribund freshwater ornamental fishes of Kerala, India. Antonie van Leeuwenhoek, 103(1), 53-67. doi: 10.1007/s10482-012-9786-z
Suhet, M. I., Schocken-Iturrino, R. P., \& Amaral, L. A. (2011). Atividade hemolítica e resistência a antimicrobianos por espécies de Aeromonas isoladas de criação intensiva de Tilápias do Nilo (Oreochromis niloticus). Ars Veterinaria, 27(1), 36-44. Retrieved from http:// arsveterinaria.org.br/ars/article/view/381

Tacon, A. G. J. (2020). Trends in global aquaculture and aquafeed production: 2000-2017. Reviews in Fisheries Science \& Aquaculture, 28(1), 43-56. doi: 10.1080/23308249.2019.1649634

Wagatsuma, S. (1968). A medium for the test of the hemolytic activity of Vibrio parahaemolyticus. Media Circle, 13(1), 159-161.

Zucker, E. (1985). Hazard evaluation division: standart evaluation procedure: acute toxicity test for freshwater fish. Washington: U. S. Environmental Protection Agency. 
